\title{
Informality in organization and research: a review and a proposal
}

\author{
J. A. Rooke, L. J. Koskela \& M. Kagioglou
}

\begin{abstract}
The growing interest in informal and emergent features of organizations has accompanied changes both in the dominant forms of organization and prevailing academic views about how best to think about and research them. It is argued here that currently espoused dichotomous characterizations of both organizations and research approaches are over-simplified and misleading.

A review of types of organisation research is conducted and it is suggested that the relationship between theory and data collection provides a more detailed and illuminating taxonomy than a distinction between qualitative and quantitative research. Two major distinctions are proposed: [1] between theory driven and phenomenon driven research; [2] between descriptive and prescriptive theory. It is suggested that organization theory is properly prescriptive in nature.

The place of informality in organization and management studies is explicated, drawing on insights from Wittgenstein and ethnomethodology (EM). A distinction is drawn between [1] the degree of formality in particular organizational settings and [2] the necessarily informal foundations of formal organizational schemes and methods.

Finally, the organization of research itself is addressed. A prescriptive theory (TFV) is suggested as a means of organizing and accounting for the research process. This suggestion serves as both [1] a proposal for research management and [2] an illustration of the relationship between theory and organization.
\end{abstract}

\section{Keywords}

Research methods; Research policy; Organization theory; Organizational analysis; Production process.

\section{Introduction}

An interest in informal and emergent features of construction industry organization has grown over the past two decades, particularly in the UK. It is also fair to say that the majority of this work can be broadly termed 'qualitative' and that this type of research is increasingly apparent in the literature. When the Tavistock study (Higgin \& Jessop 1965), the comparison of traditional and bureaucratic methods in construction management by Applebaum (1982), and later Organizing Construction (Bresnen 1990) were published, these all represented relatively isolated attempts to come to grips with the complexity of local organizational realities on construction projects. Since then much has changed and a number of such studies now exist. A selection from one recent year includes: Bresnen (2007); Chang \& Kaka (2007); Johnstone, Dainty \& Wilkinson, (2007); Luck (2007); Räisänen \& Gunnarson (2007); Rooke, Koskela \& Seymour (2007). These studies constitute a healthy and growing minority of construction management publications. 
Below, we discuss the best way to characterize these studies and suggest a way forward in developing them. We begin by examining the common assumption that research can be comprehensively classified as either quantitative or qualitative, using an example of quantitative research to illustrate the ways in which it requires considerable interpretative work to underpin the identification and measurement of variables. We suggest, then, that this categorization is misleading and describe an alternative approach that more clearly details the range of research alternatives on offer. Two major distinctions are proposed: [1] between theory driven and phenomenon driven research; [2] between descriptive and prescriptive theory.

We warn against confusing organizational form and chosen research methods. While changes in organizational form and approaches to research may have developed simultaneously, there is no logically necessary relationship between the two.

Finally, we propose an approach to construction management research that offers the possibility of capturing both the formal and informal aspects of organization in such a way as to support the emergence of practical management applications. The purpose of this proposal is two-fold, in addition to offering a practical proposal for research management, it is intended as an illustration of the relationship between prescriptive management theory and a management practice which is sensitive to the informal and emergent features of organization.

\section{The conventional typology of research approaches}

Construction management research tends to borrow from disciplines such as sociology, in order to characterize research approaches as either qualitative or quantitative. The former are seen to be reliant on interpretative procedures, while the latter are held to have an objective status. However, this distinction is illusory, as is shown below, where a quantitative study is examined to reveal the interpretative procedures upon which it fundamentally depends. It should be apparent that this dependence is not a peculiarity of the study in question, but that similar observations could be made of any such quantitative studies of real world phenomena.

Duff, Robertson, Cooper and Phillips (1993) set out to measure and improve site safety on six construction sites using the following method: develop measures of safety performance; introduce techniques to change behaviour; use the measure to test the effectiveness of the behavioural technique; and develop from the results, general guidelines for managing such behavioural change.

Thus, the study seeks to establish causal relationships between two methods of goal setting, feedback and training, on the one hand, and outcomes in terms of safety indicators on the other. The indicators are designed to be quantifiable, in order to facilitate objective comparison between the different types of intervention. The method is actually a variation of the experimental method associated with scientific laboratory research. In the context of a laboratory, a controlled environment is established, within which carefully defined variables can be manipulated and the effects recorded. Two kinds of difficulties arise in transferring this approach to a construction site: how stable definitions of variables will be established; and how the process will be controlled in order to isolate the variable of interest and keep all others constant.

Two kinds of consideration are operative in the definition of variables. The 
phenomena on which the research focuses must be relevant to the problem at hand, in this case the problem of safety; but, equally important, is to make the relevant phenomena findable. That is to say, they must be available to the researcher as observable phenomena. In the case of a quantitative study this means that the phenomena must be countable. The countability of phenomena is partly dependent on the existence of a good operational definition, of the phenomenon to be counted. Such definitions must be rigorously maintained, if any meaningful counting of cases is to take place.

Several measures designed to control for unwanted variables are introduced. A long lead time is employed, during which data is collected but not used, in order to eliminate any Hawthorne effect (Mayo 1945). In addition to the three categories of safety behaviour monitored for the experiment, a fourth was monitored as a control: changes in data from this category, which did not arise from the researchers manipulation of independent variables, could be attributed to external factors causing a general change in safety performance. The commencement of research on the six sites was staggered at four week intervals, as a further control against undefined external interference. Additional control sites were monitored. Additional information was collected during site visits, which "permitted some tentative explanations to be given about variation in performance within and between sites which did not appear to be a direct result of the experiment." (p. 15)

The careful and detailed elaboration of the experimental controls used in this study make it an exemplar of its kind. However, the nature of these controls illustrate the difficulty of maintaining 'laboratory conditions' in the real world. They constitute a series of measures designed to guard against unforeseen variations in conditions. Apart from the Hawthorne Effect, no attempt is made to specify what the nature of these variations might be. Thus, it is difficult to assess their effectiveness. This difficulty is reflected in the multiplicity of controls which are used. The final control consists in additional data collected during site visits. In other words, upon the alertness and common sense of the observers, in spotting variations in conditions which were likely to affect the results, demonstrating the dependence of such formal experimental studies on the same kind of informal methods used in ethnographic research.

The independent variables in this study were the interventions described above. These are the easiest part of the process to define and control, since they consist in the actions of the research team. However, even here, a degree of uncertainty must arise and the inevitable question is: what degree of control should be considered adequate? For example, it was felt necessary to control the method of introducing goals to operatives, so that one set of operatives would not be more encouraged to aspire to the goals than another set. This was done by writing a script, ensuring that each set of operatives was told exactly the same thing about the goals. However, other possible variables were not controlled. There was no attempt to make sure that the script was always delivered by the same person, for example. Thus, there was no control over personality differences among researchers which might have influenced style of delivery and thus operative commitment to the goals.

Despite the rigorous implementation of this study, it seems that there is no possibility of final closure in the logic of the methodology. However many controls are put in place, there will always be further questions which could be asked. Thus, if the experimental design had stipulated that the goal introduction script was to be 
delivered each time by the same person, or an attempt had been made to define the tone, style of delivery and level of enthusiasm with which the script was delivered, then further questions would immediately arise. Thus, for instance, questions could be asked about the location of the delivery, the size of the meeting at which the delivery was performed, the evident level of endorsement of site and senior management, etc.3. An alternative typology

Rooke (2007) suggests five types of research, categorized according to the role of theory in their methodology:

1. uniquely adequate (meeting the strong requirement);

2. grounded theorizing;

3. theoretically informed;

4. formal;

5. action/construction.

These are further classified according to two distinctions: whether or not they meet the strong requirement of unique adequacy; and whether they are empirically, or theoretically driven (see Table 1). They are briefly reviewed below, As should be apparent, they do not represent tightly exclusive categories. There are practices that reside on the borderlines of each type. The first four types are described here as descriptive in nature, to distinguish them from the fifth, which consists of what has been variously termed action research (Argyris, Putnam \& Smith 1985; or constructive research (Kasanen, Lukka \& Siitonen 1993) or design science research (March \& Smith 1995). Clearly, this distinction is not the only one that can be drawn, in particular, our category 'descriptive' includes research of an explanatory or predictive nature, in addition to other forms of description.

\section{Four types of descriptive research}

1. Uniquely Adequate (UA) (Strong Requirement). The twin requirements of UA (Garfinkel \& Weider 1992; Garfinkel 2002) have been introduced to the construction management literature elsewhere (Rooke 1997; Rooke \& Kagioglou 2007). Briefly: the weak requirement stipulates that the author of a research report should have an everyday practical competence in the setting reported; the strong requirement restricts the analytical devices used in the report to those already present in the setting. It is not clear that all research meeting the strong UA requirement could necessarily be properly called ethnomethodology. Strong UA is negative in effect, refusing the use of theory to inform fieldwork. The latter represents a positive interest: a focus on the detailed analysis of members' methods for the creation of social order, as those methods are employed in practice. The crucial point to note about such research is that it is not interpretative as the term is currently widely understood. That is because the fact of organizational arrangements is locally and inter-subjectively achieved on an ongoing basis, as an outcome of the concerted activities of the organization's members (Schutz 1973).

2. Grounded Theorizing Grounded theory research should meet the weak requirement. It may or may not meet the strong requirement. Indeed, disagreement has arisen between the founders of the approach (Glaser 1992; Corbin \& Strauss 1998) as to whether it is legitimate to introduce pre-formulated theoretical terms into 
grounded theory analysis. Others have wished to broaden the approach still further (though in a somewhat different direction), stipulating only that theorizing should take place simultaneously with fieldwork (Charmaz \& Mitchell 2001). At one extreme, then, it can be difficult to distinguish between grounded theory and UA research; at the other, between grounded theory and theoretically informed research. Grounded theory work that has been carried out in construction management includes, for instance, Dainty, Bagilhole \& Neale 2000; Rooke, Seymour \& Fellows 2003; Dainty, Bryman, Price, Greasley, Soentanto \& King 2005).

3. Theoretically Informed. The term 'theoretically informed research' refers here to research that draws upon theory in a manner that is not formally specified. There are a wide variety of approaches that fall into this class. At one extreme, theory may be drawn upon in ad hoc manner to explain, or elucidate findings. From the pragmatic point of view of a management discipline, it may have something to recommend it, as it allows for the cherry-picking of useful ideas, without the need for rigorous intellectual justification. Then again, such ad hoc theorizing might be a form of grounded theorizing as mentioned above. It might be an adjunct to an exploratory, or scoping study. It might be a preliminary to a more systematic theoretical development, or application of already existing theory. At the other extreme, it might be research which arises from a principled application of existing theory, but uses informal ethnographic or historical methods to test or extend this. To the extent to which research is theoretically informed, it does not meet the strong requirement (Rooke 1997; Rooke \& Kagioglou 2007). An alternate reporting criterion is Schutz's (1973) Postulate of Adequacy. This stipulates that the theoretical concepts used should be understandable by members of the research setting in common sense terms. In this way, the point(s) of view held by the subject(s) of the research are taken into account in the formulation of theory. Whatever level of theorizing is achieved, it is important that the theory remains true to its empirical referents. Thus, observation of the weak requirement remains a useful test of the validity of the findings.

4. Formal Research. This is a type of theoretically driven research which follows, or is represented as having followed, a pre-conceived plan. This is a very common approach in construction management, even for the investigation of acknowledgedly 'soft' topics, such as culture or behaviour change. Duff et al (1993) falls into this category, as do other quantitative survey studies. A positivist model may be adopted, such that a hypothesis is generated from an established body of theory. A research protocol is then devised which is intended to test the hypothesis and thus contribute to the orderly growth of knowledge. On the other hand a comparative approach may be used to test a hypothesis. Alternatively, an interpretative scheme may be adopted simply in order to classify members of a population (see for instance Fellows, Liu, \& Fong 2003)).

The results of such enquiries tend to take a statistical form. These studies still constitute the majority in construction management. As with theoretically informed research, the strong unique adequacy requirement is not pertinent to formal research, but the application of Schutz's Postulate of Adequacy and the weak form of the requirement remain relevant. 


\section{Type five: another kind of theory}

Management, like engineering, is not simply a descriptive discipline. Its theories are prescriptive, they are guides to doing things in the world (Koskela 2008). It follows that these disciplines are best served by research which is also not just descriptive in nature. Aristotle (1976) identifies three kinds of inquiry: epistēmē, translated as 'science', with the implication that it is descriptive in nature; techne, translated as art, or technical skill; and phronēsis, translated as prudence, or practical wisdom, concerned with morals and political deliberation. Several modern approaches echo these distinctions, some in part, others more fully, including: Simon's (1996) notion of artificial science; Argyris, Putnam \& Smith's (1985) action science; constructive research (Kasanen, Lukka \& Siitonen 1993); mode 2 research (Gibbons, Limoges, Nowotny, Schwartzman, Scott \& Trow 1994; or the direct application of phronessis (Flyvbjerg 2001; Cairns 2008).

As is apparent from the review of Duff et al (1993), a function of theory is to distinguish between those phenomena that are of interest in the research (whether these are quantifiable variables, or more broadly defined aspects of the research setting) and those phenomena that are of no interest. The limitation of theory driven modes of research is that research reports written from particular theoretical standpoints will only partly reflect the methods used by members of an organizational setting to maintain and manage that setting. Where the researcher's theory is not also held by the other members of the setting, this can lead to a serious distortion in the reporting, such that members understandings are re-interpreted in order to fit the theory (Rooke \& Kagioglou 2007). Even where the theory is accepted by members and used by them in the management of the setting, the research will inevitably be biased towards reporting theorized phenomena and overlooking those phenomena that are not accounted for in the theory. Some of these may be of key importance to the topic of the research.

On the other hand, if theories in management are exercises in techne or phronēsis, then they are intended as prescriptions, rather than aids to better description. As Rooke \& Kagioglou (2007) have shown, reports on theoretically based interventions can be made to meet the strong requirement of UA. This is because, within the context of such studies, theory can be made a topic of, rather than a resource for, the enquiry. This requires making and maintaining a clear distinction between the theory driven intervention and the UA investigation of the closely related phenomena of how it is carried out and how it is received.

The nature and role of theory in technē and phronessis is less clear. Simon (1996), for instance, seems to treat both engineering and social research as exercises in techne, which he reduces to an exercise in logical choice, in line with decision theory. Kasanen, Lukka \& Siitonen (1993) might be seen as more closely following Aristotle's own formulation of techne. Argyris, Putnam \& Smith's (1985) approach seems more akin to phronēsis, but nevertheless seeks to retain key elements of epistēme , notably the logic of experimental method. Gibbons, Limoges, Nowotny, Schwartzman, Scott \& Trow (1994) are less sanguine than any of these, cataloguing many of the problems attendant on the interface between science and the public domain, problems that largely fall under the domain of phronessis. Following Winch (1990), Hutchinson, Read \& Sharrock (2008) might be making an argument for phronesis, when they assert that the key logical relationships in the study of human 
organization are criterial, rather than causal. Flyvbjerg (2001) directly adopts Aristotle's distinction, suggesting that phronēsis is the appropriateway to characterise social science, while Cairns (2008) spells out its significance for construction managment.

\section{Forms of organization and forms of research}

Although Saddler \& Barrie's (1970) study of organizational structure was largely informed by Weber's (1947) model of bureaucracy as the ultimate rational organization, it nevertheless established the existence of another type of effective organizational form, perhaps better suited to the emerging fluid global economy. This 'organic' form of organization (Burns \& Stalker 1961), with its emphasis on shared values and loose central control, is comparable to that controversially celebrated by Peters \&Waterman (1982). Since then, the advent of the 'post-modern' organization, replacing centralised control with complex and fluid methods of coordination, has been widely celebrated (See, for example, Clegg 1990; Handy 1995). But we are left with a certain lack of clarity regarding forms of organization and forms of research.

By contrast, Suchman's (1987) widely influential critique of planning models consists principally of an investigation into the nature of organization that demonstrates the informal basis of all organizational arrangements, however traditional they may be in form. Thus, although it contains a critique of the naïve use of formal organizational designs, it is not concerned with distinguishing between, or evaluating organizational forms. The principal message for management studies is that all forms of organization are best researched through informal methods. Thus, there is no reason to suppose that classic bureaucracies are not susceptible to informal methods of study. On the contrary, as Zimmerman's (1971) classic work on rule following in a welfare agency shows, following formal bureaucratic rules requires a great deal of informal organizational work. Moreover, the uses made of formal organizational schemes can vary tremendously, making their relationship to organizational reality always problematic to the researcher (Bittner 1973; Dant \& Francis 1998). Neither though should the implications of Suchman's work be exaggerated, as Schmidt (1999) notes, organizational planning documents can sometimes provide adequate accounts of their implementation, if the planned action is sufficiently routine.

Nor is it unreasonable to suppose that different forms of organization may require different research techniques to capture their particular features. Clearly, bureaucracy also lends itself to quantitative study, if only because of the quantitative data it produces as an integral part of its functioning. Thus, we have studies using secondary data that date back (and usually owe much to) Durkheim's (1951) work in the nineteenth century. In parallel, quantitative research methods, with their use of forms and tick boxes, have developed to mirror these bureaucratic practices. What matters is the way such data are viewed. They should be recognized for the organizational artefacts that they are. Just as we would learn something about an iron age settlement by studying the artefacts it produces, we can learn something about an organization by studying the statistical data it produces. Thus, while such data should not be dismissed, the organizational features of their production (whether these are features of business organization, or research organization) should not be lost sight of in the subsequent analysis. Unfortunately, this is often overlooked; by its very nature, such data tends to obscure its provenance, while its numerical form tends to overly impress many researchers who have a näive view of science. On the other hand, to assert that 
such data are any less 'real' that those generated through an interview, for instance, is to overlook the ways in which all data are shaped by the setting in which they are produced. Thus the question of what the quantitative data output of an organization tells us about that organization is a complex one, probably best dealt with on a case to case basis.

Meanwhile, the ethnographic participant observation approach which originated as a way of studying remote village communities has long since 'come home', first to the city street (Burgess 1984) and then to corporate office (Watson 1994). As formal and centralized control becomes less important, it may be argued, so the study of informal and emergent order becomes more urgent; and as classic bureaucracy lends itself to study through the production of statistical data, so the post-modern organization requires new methods to render it accessible to study. However, there is no agreement that these methods will necessarily be exclusively qualitative. Rooke, Molloy, Sinclair, Koskela, Siriwardena, Kagioglou \& Siemieniuch (2008) note two approaches to the study of complexity in organization theory, characterizing them respectively as 'model' and 'metaphor'. While models are concerned with the identification of key variables, metaphors intend to provide new forms of interpretation. A crucial point made here about mathematically based complexity models of organizations and their environments is that such models should not be treated as predictive, but only exploratory.

Thus, the consequences of Suchman are complex, while informal methods of research and organization can both be seen increasing in their relative importance, there is no clear and simple connection between these two phenomena. The key point to note is that both formal organization and formal research methods have an informal social basis; and this basis is social. This is clearly demonstrated in the writing of Garfinkel (1984) which underpin Suchman's own work. Rules are endlessly interpretable. What makes them nonetheless determinate is that they are subject to agreement and must be so if human organization is to be possible at all.

As Wittgenstein (1958) points out,

"if everything can be made out to accord with the rule, then it can also be made out to conflict with it. And so there would be neither accord nor conflict here. [...] What this shows is that there is a way of interpreting a rule which is not an interpretation, but which is exhibited in what we call 'obeying the rule' and 'going against it' in actual cases." (\#201)

But in order to understand a rule in this way, we must first have a concept of what a rule is (a concept of uniformity, of sameness). Wittgenstein shows us the nature of this understanding by answering the question: how could anyone come to acquire such a concept? "I shall shew him the same colours, the same lengths, the same shapes, I shall make him find them and produce them, and so on." (1958:\#208). Thus, rule following demands practice, in Ryle's (1963) terms, 'knowing how'.

Furthermore, this practice is inescapably social, it is the availability of rule following behaviour for public scrutiny that makes it rule following, "otherwise thinking one was obeying a rule would be the same thing as obeying it." (Wittgenstein 1958:\#202)

For Garfinkel, its is apparent that accurate accounts of human organization depend upon a detailed understanding of these practical social procedures. Organizational order is inherent in the the practical activity of understanding, following, interpreting, making and even breaking rules. This radical view rejects the perceived need for a 
theory in order to account for or explain organizational realities as we find them in the world. Garfinkel \& Wieder's (1992) introduction of the strong UA requirement enshrines the principle that the activities and procedures of persons in a setting can best be accounted for in terms of the understandings that those persons have of that setting. Rooke, Molloy, Sinclair, Koskela, Siriwardena, Kagioglou \& Siemieniuch (2008) illustrate the implications of this approach through Sacks' (1963) 'commentary machine' metaphor and Livingston's (1987) example of pedestrian behaviour at a busy road junction, pointing to its convergence with a tendency for complexity scholarship to focus on the analysis of perceptions from particular identified points of view (see Smallwood, 2000; Bertelsen, 2004; Bertelsen and Emmitt, 2005; Bresnen, Goussevskaia and Swan 2005; Elhag, Boussabaine and Ballal, 2005). The alternative is to generate a series of false oppositions which are, in themselves, sources of further complexity, between, for example: human agency versus social structure (Giddens 1984); subjective 'trustworthiness' versus objective 'truth' (Lincoln \& Guba 1985); or constructivism versus realism (Delanty 1997).

\section{Researching emergence and informality}

For Aristotle, the key difference between epistēme, on the one hand and technē and phronesis, on the other, is that the former is concerned solely with that which is invariable. Thus, phronēsis,

"is not concerned with universals only; it must also take cognizance of particulars [...] [it] is practical, and therefore it must have both kinds of knowledge." (Aristotle 1976:1141b8-27)

Thus, the articulation of generic and the particular knowledge is a key concern to be addressed, one that has exercised, among others, the sociological writers cited at the end of the last section and which appears to take on an increasing importance with the growth of informal organization.

One solution that has been suggested is to treat research as a customer-supplier relationship (Seymour, Rooke \& Crook 1996). This implies that research is seen as a type of production. In this section, we suggest one way in which an approach to researching informal features of organization might be developed, using the TFV theory of production (Koskela 2000). This generic theory stipulates that production should simultaneously be conceptualized and managed as transformation, flow and value generation.

The TFV theory is principally techne based, but the V analysis, with its emphasis on the customer at the head of the supply chain, involves the weighting of different customer needs (originating from different directions: management, funder, users, etc.), a concern which falls under phronessis. It should be noted that the proposal outlined here does not directly concern the application of TFV to construction management settings, rather, it is a proposal for the management of the research process itself. In this way, the TFV constitutes a formal organizational scheme (Bittner 1973). Thus, the relationship between the TFV theory and the actual realtime organization of the research is directly analogous to that which pertains between plans and actions in any other organizational setting.

We adopt an order of analysis which proceeds from value to transformation and then to flow, allowing each theoretical component to pose a different question for us. This 
would seem to be a naturally logical way to proceed, beginning with the customer, then analysing the transformation of resources into products, before finally examining the processes necessary for this transformation. Thus, we ask: first, who is the customer and what do they want? (Value); then, what do we have and what can we deliver (and how)? (Transformation); and finally, how do we eliminate waste and achieve maximum efficiency? (Flow).

We can establish three different categories of customer for research in construction management: industry; academic readership; and funding bodies. Industrial customers require clear practical guidance at the time and place that it is needed. By contrast, an academic audience demands findings with a more abstract and discipline specific relevance. The problem of balancing these demands has long been widely discussed (e. g. Hodgkinson 2001). Funding bodies often attempt to balance these competing demands, sometimes using metrics, which tend to become attainment targets in their own right. These can take priority over the requirements of other user groups, since funding is an essential pre-condition of research. This may lead to a situation similar to that faced by construction contractors in competitive tendering situations where economic values come into conflict with technical ones (Rooke, Seymour \& Fellows 2003). Thus, the problem is to design and deliver academic outputs that can (either simultaneously, or successively) satisfy the differing criteria of the three customer categories. This requires audience analysis and careful discrimination (though not necessarily selection) between criteria (Rooke \& Seymour 2005).

In transformation terms, the research process consists in turning academic knowledge and skills into research outputs: books, papers and presentations for academics; more usually workshops and tools for companies. The problematic that a transformation view highlights is that of identifying and mobilizing the academic inputs that can fulfil the three sets of customer requirements in any particular case. These include methodological considerations such as the selection of research approach and methods.

The questions raised by the flow perspective highlight the question of efficiency in the process: the elimination of waste. On one level, this raises issues such as the effects of long lead times for journals, the quantity of publications that add little to the existing body of knowledge, and the duplication of work, not simply in different universities, but between disciplines and over time, as the wheel is continually rediscovered. On a deeper level, it brings into question the accepted basis for academic standards in epistemene. It is currently assumed that these standards of truth act as a warrant for the applicability of the findings, because if they are right, they must also be applicable. However, there is no necessary logical warrant for this, if organizational research is recognized as belonging to an autonomous sphere of techne or phronēsis.

\section{Conclusion}

This paper represents an attempt to move beyond the simple dichotomies of formal and informal organization on the one hand and qualitative and quantitative research on the other. In doing so, it has been argued that both formal research and formal organization have informal bases. From this insight, we have demonstrated an alternative typology of research approaches, and made some initial investigation of 
their relevance to various research purposes and settings.

While these types are largely based on a clear dichotomy within the sphere of epistēme between theoretically driven and uniquely adequate research, it requires a further distinction between descriptive epistēme theory on one hand and prescriptive techne or phronēsis theory on the other, to identify what may prove to be the most interesting and useful of the five categories. In this last category, the role of theory is very different and may indeed take more than one form, but it is essentially prescriptive, rather than only explanatory or predictive.

We have drawn principally on two sets of arguments: about the correct relationship between theory and research; and about the correct nature of management theory. We have proposed an approach to research management that assumes one particular set of resolutions to these questions. The proposal demonstrates the application of a formal prescriptive theory of management to the problem of researching informal features of organization. Crucially, in this approach, theory does not inform the fieldwork, but governs the research management process. This means that there is no logical contradiction between the application of the UA requirement and the TFV theory. The first governs the investigation and reporting of particular settings, ensuring that understandings and reports do not depart from the internal logic of these settings. The latter governs the analysis and planning of work and process.

Thus, the application of TFV to research management acts as a demonstration of the role that prescriptive theory can play in actual organizational arrangements. The relationship between the theory and the actual real-time organization of the research is directly analogous to that which pertains between plans and actions in any other organizational setting. If our characterization of the nature of management theory as techne and/or phronēsis is accepted, then this is also the correct relationship between theory and action in an organizational setting.

Clearly, this is not the final word on the matter. The nature of construction management research as techne and/or phronessis will require further clarification, while the variety of candidate theories and theory/research relationships promises to offer competing proposals to the one we have made here. These will face their ultimate test in the practice of research management and in management practice more generally. The objective of this note has been merely to raise these issues and offer a proposal.

\section{References}

Applebaum, H.A. (1982) Construction Management: Traditional versus Bureaucratic Methods. Anthropological Quarterly, Vol. 55, No. 4, pp. 224-234.

Argyris, C., Putnam, R. \& Smith, D. M. (1985) Action Science, Josey-Bass, San Francisco. http://www.actiondesign.com/action_science/

Aristotle (1976) The Ethics of Aristotle: The Nicomachean Ethics, J. A. K. Thompson (Trans.), Revised Edition, H. Tredennick (Rev.), Penguin, Harmondsworth.

Bertelsen, S. (2004) 'Construction management in a complexity perspective', in Aouad, G., Amaratunga, D., Kagioglou, M., Ruddock, L. and Sexton, M. (Eds.) Proceedings of the first international SCRI symposium, March, Salford Centre for Research and Innovation (SCRI) in the Built and Human Environment, University of 
Salford, $346-355$.

Bertelsen, S. \& Emmitt, S., 2005, 'The client as a complex system', in First, I. (Ed.) Proceedings of the 13th Annual Conference of the International Group for Lean Construction, International Group for Lean Construction, Sydney, Australia, 73-80, ISBN: 18-7704-034-7.

Bertelsen, S., Henrich, G., Koskela, L. \& Rooke, J. (2007) 'Construction physics' in C. L. Pasquire, \& P. Tzortzopoulos (Eds.) Proceedings of the 15th Annual Conference of the International Group for Lean Construction, Michigan State University, East Lansing, 13-26.

Bittner, E. (1973) 'The Concept of Organization' in G. Salaman \& K. Thompson (Eds.) People and Organizations, Longman, London, reprinted from (1965) Social Research 32(3):239-255.

Bresnen, M. (1990) Organizing Construction: Project Organization and Matrix Management, Routledge, London.

Bresnen, M. (2007) 'Deconstructing partnering in project-based organization: seven pillars, seven paradoxes, seven deadly sins,' in International Journal of Project Management, 25(4):365-374.

Bresnen, M., Goussenvskaia, A. \& Swan, J. (2005) 'Organizational routines, situated learning and processes of change in project-based organizations,' in Project Management Journal, 36(3):27-41.

Burgess, R. G. (1984) In the Field: an introduction to field research, Allen \& Unwin, London.

Burns, T. \& Stalker, G. (1961) The Management of Innovation, Tavistock Publications, London.

Cairns, G. (2008) 'Advocating an ambivalent approach to theorizing the built environment,' in Building Research and Information 36(3):280-289.

Chan, P. W. \& Kaka, A. (2007) 'The impacts of workforce integration on productivity' in A. R. J. Dainty, S. D. Green \& B. Bagilhole (Eds.) People and Culture in Construction: a reader, Taylor \& Francis, London.

Charmaz, K. \& Mitchell, R. G. (2001) 'Grounded Theory in Ethnography', in P. Atkinson, A. Coffey, S. Delamont, J. Lofland \& L. Lofland (eds.) Handbook of Ethnography, Sage, London.

Clegg, S. (1990) Modern Organizations: organization studies in the modern world, Sage, London.

Dainty, A. R. J., Bagilhole, B. M. \& Neale, R. H. (2000) 'A Grounded Theory of Women's Career Under-Achievement in Large UK Construction Companies', in Construction Management and Economics, 18():239-250.

Dainty, A. R. J., Bryman, A., Price, A. D. F., Greasley, K., Soentanto, R. \& King, N. (2005) 'Project affinity: the role of emotional attachment in construction projects,' in Construction Management and Economics 23(3):241-244.

Dant, T. \& Francis, D. (1998) 'Planning in Organizations: Rational Control or Contingent Activity?' in Sociological Research Online 3(2)

http://www.socresonline.org.uk/socresonline/3/2/4.html 
Delanty, G. (1997) Social Science: Beyond Realism and Constructivism, OUP, Buckingham.

Duff, A. R., Robertson, I. T., Cooper, M. D. \& Phillips, R. A. (1993) Improving Safety on Construction Sites by Changing Personnel Behaviour, HSE Contract Research Report No. 51/1993, HMSO.

Durkheim, E. (1951) Suicide: A study in sociology, J. A. Spaulding (Trans.), Routledge, London.

Elhag, T. M. S., Boussabaine, A. H. \& Ballal, T. M. A. (2005) 'Critical determinates of construction tendering costs: quantity surveyors' standpoint,' in International Journal of Project Management, 23(7):538-545.

Fellows, R., Liu, A. \& Fong, C. M. (2003) 'Leadership style and power relations in quantity surveying in Hong Kong', Construction Management and Economics 21:809818.

Flyvbjerg, B. (2001) Making Social Science Matter: why social science fails and how it can succeed again, Cambridge University Press.

Garfinkel, H. (1984) Studies in Ethnomethodology, Polity Press, Cambridge.

Garfinkel, H. (2002) Ethnomethodology's Program: Working out Durkheim's Aphorism, Rowman \& Littleford, Lanham.

Garfinkel, H. \& Wieder, D. L. (1992) 'Two Incommensurable, Asymmetrically Alternate Technologies of Social Analysis', in G. Watson \& R. M. Seiler (eds.), Text in Context, Sage, London, pp. 175-206.

Gibbons, M., Limoges, C., Nowotny, H., Schwartzman, S., Scott, P. \& Trow, M. (1994) The New Production of Knowledge, Sage, London.

Giddens, A. (1984) The Constitution of Society; Outline of the Theory of Structuration, Polity, Cambridge.

Glaser, B. G. (1992) Basics of Grounded Theory Analysis: Emergence v. Forcing, Sociology Press, Mill Valley, CA.

Glaser, B. G. \& Strauss, A. L. (1967) The Discovery of Grounded Theory; Strategies for Qualitative Research, Weidenfeld \& Nicholson, London.

Green, S. D. (1999) 'The missing arguments of lean construction' Construction Management and Economics 17(2):133-7.

Green, S. D. \& May, S. C. (2005) 'Lean construction: arenas of enactment, models of diffusion and the meaning of "leanness", in Building Research and Information 33(6):498-511.

Handy, C. (1995) The empty raincoat: making sense of the future, Arrow Business, London.

Higgin, J. W. \& Jessop, W. N. (1965) Communications in the Building Industry, Tavistock, London.

Hodgkinson, G. P. (Ed.) (2001) 'Facing the Future: the nature and purpose of management research re-assessed', British Journal of Management 12(special issue):S1-S80.

Hutchinson, P., Read, R. \& Sharrock, W. (2008) There is no such thing as a social 
science: in defence of Peter Winch, Ashgate, Aldershot.

Johnstone, S., Dainty, A. \& Wilkinson, A. (2007) 'Hunters and farmers? The HRM implications of "product-service" in construction,' in CIB World Building Congress; construction for development, $14^{\text {th }}-18^{\text {th }}$ May, Cape Town International Convention Centre, 073 pp 254-265.

Kasanen, E., Lukka, K. \& Siitonen, A. (1993) 'The constructive approach in management accounting research,' Journal of Management Accounting Research, 5(Fall):243-264.

Koskela, L. (2000). An exploration towards a production theory and its application to construction, VTT Technical Research Centre of Finland, VTT Publication 408.

Koskela, L. (2008) 'Editorial: Is a theory of the built environment needed?' in Building Research and Information 36(3):211-215.

Lincoln, Y. S. \& Guba, E. G. (1985) Naturalistic Inquiry, Sage, London.

Luck, R. (2007) 'Using artefacts to mediate understanding in design conversations,' in Building Research and Information, 35(1):28-41.

March, S. and Smith, G. (1995). Design and Natural Science Research on Information Technology. Decision Support Systems 15 (1995): 251 - 266.

Mayo, E. (1945) The Social Problems of an Industrial Civilization, Harvard University Press, Cambridge, Mass.

Peters, T. J. \& Waterman, R. H. (1982) In Search of Excellence, Harper and Row, London.

Räisänen, C. \& Gunnarson, S. (2007) 'Learning to know and knowing to learn: discursive practice as knowledge enabler,' in W. Hughes (Ed.) Proceedings of the CME25: Construction management and economics: past, present and future, $16^{\text {th }}-18^{\text {th }}$ July, University of Reading, UK.

Rooke, J. (1997) 'Developing a More Empirical Approach to Culture, Attitude and Motivation in Construction Management Research: A critique and a proposal,' in Journal of Construction Procurement, 3(2):45-55.

Rooke, J. (2007) 'Varieties of Relationship Between Research and Theory,' Towards the Foundation of Theory for the Built Environment 139-148, Digital World Centre, Salford, 18th -19th June.

Rooke, J. \& Kagioglou, M. (2007) 'Criteria for evaluating research: the unique adequacy requirement of methods,' Construction Management and Economics, 25(9):979-987.

Rooke, J., Koskela, L. \& Seymour, D. (2007)'Producing things or production flows? Ontological assumptions in the thinking of managers and professionals in construction,' Construction Management and Economics 25(10):1077-1085.

Rooke, J., Molloy, E. M., Sinclair, M., Koskela, L., Siriwardena, M., Kagioglou, M. \& Siemieniuch, C. (2008) 'Models and Metaphors: Complexity Theory and ThroughLife Management in the Built Environment,' in Architectural, Engineering and Design Management 4(1):47-57.

Rooke, J. \& Seymour, D. (2005) 'Studies of Work: Achieving Hybrid Disciplines in 
IT Design and Management Studies', Human Studies 28(2):205-221.

Rooke, J., Seymour, D. \& Fellows, R. (2003) 'The Claims Culture; A Taxonomy of Industry Attitudes', in Construction Management and Economics, 21(2):167-174.

Rooke, J., Seymour, D., Koskela, L., Bertelsen, S., Owen, B. \& Cleary, M. (2008) 'Inquiry Pull Research: an ethnomethodological approach to lean construction research or a lean approach to ethnomethodological research?' 1GLC16: Lean Construction: Making a Difference, MacDonald Manchester Hotel - Piccadilly Suite, Manchester, UK, 16-18 July.

Ryle, G. (1963) The Concept of Mind, Penguin, Harmondsworth.

Sacks, H. (1963) 'Sociological Description,' in Berkeley Journal of Sociology, 8:1-16.

Sacks, H., Schegloff, E. A. \& Jefferson, G. (1974) 'A Simplest Systematics for the Organization of Turn-Taking for Conversation', in Language, 50:696-735.

Sadler, P. \& Barry, B. (1970) Organisational Development, Longmans, London

Schmidt, K. (1999) 'Of maps and scripts: the status of formal constructs in cooperative work,' Information and Software Technology 41(6):319-329.

Schutz, A. (1973) The Problem of Social Reality (Collected Papers, Volume 1) M. Natanson (Ed.) Marinus Nijhoff, The Hague.

Seymour, D., Rooke, J. \& Crook, D. (1996) 'Research as a customer-supplier relationship', in ARCOM 96: Proceedings of the Twelfth Annual Conference of the Association of Researchers in Construction Management, Sheffield Hallam University, 10-12 September, 448-457.

Simon, H. A. (1996) The Sciences of the Artificial, Third Edition, MIT Press, Cambridge MA.

Smallwood, J., 2000, 'Contractor performance: clients' perceptions', in A.B. Ngowi and J. Ssegawa (eds), Challenges Facing the Construction Industry in Developing Countries, Proceedings of the 2 nd International Conference of the CIB Task Group 29 (TG29) on Construction in Developing Countries, November, CIB, Gaborone, Botswana, 128-138.

Strauss, A. L. \& Corbin, J. (1998) Basics of Qualitative Research: Procedures and Techniques for Developing Grounded Theory (second edition) Sage, London.

Suchman, L. (1987) Plans and Situated Actions, Cambridge University Press.

Turner, J. R. (2006a) 'Towards a theory of project management: the nature of the project', in International Journal of Project Management 24(1):1-3.

Turner, J. R. (2006b) 'Towards a theory of project management: the nature of project governance and project management', in International Journal of Project Management 24(2):93-95.

Turner, J. R. (2006c) 'Towards a theory of project management: the functions of project management', in International Journal of Project Management 24(3):187-189.

Turner, J. R. (2006d) 'Towards a theory of project management: the nature of the functions of project management', in International Journal of Project Management 24(4):277-279. 
Watson, T. J. (1994) In Search of Management, Routledge, London.

Weber, M. (1947) The Theory of Social and Economic Organization, T. Parsons (ed.), A. M. Henderson \& T. Parsons (trs.), The Free Press, New York.

Whetten, D. A. (1989) 'What constitutes a theoretical contribution?' in Academy of Management Review, 14(4):490-495.

Whetten, D. A. (2001) 'Modelling-as-theorizing: a systematic methodology for theory development' in D. Partington (Ed.) Essential Skills for Management Research, Sage, London, 45-71.

Winch, P. (1990) The Idea of a Social Science and its Relation to Philosophy (second edition) Routledge and Kegan Paul, London.

Wittgenstein, L. (1958) Philosophical Investigations (second edition) Blackwell, Oxford.

Zimmerman, D. (1971) 'The practicalities of rule use,' in J. Douglas (ed)

Understanding Everyday Life, Routledge, London. 